\title{
Sound and Meaning: Ralph Ellison's Record Collection
}

\section{Todd Weeks}

During the summer of 2006, a heat wave spread throughout most of the United States and Canada, and by the end of August, at least 225 people had died as a result of the unrelenting high temperatures. The weather was particularly bad in the Southwest, and in Oklahoma City twelve deaths were blamed on the heat. In Queens, New York, at the end of July, there was a series of power outages that left at least 10,000 residents without electricity for over a week.

At that time, I was living in Brooklyn with my wife and daughter, struggling to finish a book, and working as a guest lecturer for the Bard (College) Prison Initiative. One afternoon, I got a phone call: Fanny McConnell Ellison, the widow of Ralph Ellison, had died the previous fall, and the estate was soon to be settled. Would I consider coming, as soon as possible, to the Ellison apartment on the Upper West Side so that I could take a look at the author's record collection? There was no proviso for the records in the will, and the collection needed a home.

The Ellisons had already made provisions for those artifacts, manuscripts, letters, source materials, working notes and first editions that were deemed to be of consequence. They ended up at the Library of Congress. The rest of the contents of the apartment, including the furnishings, according to the Ellisons' last wishes, were to be liquidated - and the proceeds were to go to charity. "Liquidation" in this context meant that they were to be sold to the lowest bidder - a hauling company - and thence, to the dumpster. 
I had the time and the inclination to make the trip, which amounted to about an hour's train ride. I grabbed an artifact of my own, a 1990s era recording Sony Walkman, and headed for the subway.

I had been a devotee of Ralph Ellison since my post-college days on the north side of Chicago, when I had devoured his novel—Invisible Man — during the sweltering summer of 1989. That year, Spike Lee's Do the Right Thing and Tim Burton's Batman were in theaters, and the North American Drought of 1988 was still in full force. In Chicago, it seemed as if there were rarely a day when the temperature dropped below ninety degrees. In what since then has become clear to me was a highly implausible scenario, the Cubs were in a pennant race. On some days, when the winds were right, my roommates and I could hear the sound of the cheers from Wrigley Field, several blocks away, as they floated through the open windows of our apartment, just seconds after they blared from the speakers of our giant cathode ray Magnavox color television.

Ellison's book had a strangely hypnotic effect on me; the surreal episodes were a perfect complement to my mildly disoriented state, brought about by the recent exodus of my closest college chums for Los Angeles and New York, the hasty, unannounced departure of my live-in girlfriend several months earlier, and the unbelievably oppressive heat. As claustrophobic as the book felt at times, there was also a sense of a vast psychological space just behind the prose, which was perhaps the most elegant and powerful I had ever encountered.

What I did not know about Ellison at the time was that he was to have an impact on me far into my mature adulthood, and that his was a perspective I would come to study and absorb, especially given the value he placed on American vernacular music, which was becoming increasingly important to me. This reconciliation of sound and meaning was given full voice in Ellison's essays, especially those that dealt, not unromantically, with his boyhood experiences growing up alongside seminal jazz musicians in prohibition era Oklahoma City. I felt prepared for whatever awaited me at the Ellison apartment, which was in the Beaumont, an eleven-story building on the corner of Riverside and 150th Street in Manhattan.

After negotiating the building's lobby, which, despite its impressive marble floors and majestic staircase had definitely seen better days, I was met at the front door of apartment $8 \mathrm{D}$ by a representative of the law firm that administered the Ellison estate. I was informed that I had an hour to check out the collection, draw my conclusions, and leave. She was there to act as chaperone. The air was insufferably close. Although the open windows afforded a good view of the Hudson River, there was no breeze to cool things down. I went to work.

The records were in the living room in a marble topped credenza that sat along one wall next to a glass coffee table. Most of the paintings and sculptures had already been removed, but Ellison's workspace was still more or less intact; his desk was there. I remember seeing musical instruments (a clarinet?) and other tchotchki such as seashells, ashtrays and the like. 
I knew that when I agreed to help out I would have limited time- - hence the tape recorder. Turning on the Walkman, I began to flip through the records in the same manner that one does (or used to do) when browsing through the bins at J \& R Music or Academy Records in Manhattan. As I handled each disc, I read the name of the record, the name of the artist, and the record label into the tape recorder, making notes on the condition of each piece and of its presumed value. An early blues 78 record by Charlie Patton or Blind Lemon Jefferson might bring several thousands of dollars at auction. Rare, early, or original pressings would denote a higher value, but a record's condition would ultimately dictate its playability and the sound quality and hence its market value. Of course, these records belonged to Ellison, so there was a more complicated dynamic at play when attempting to determine their worth.

As each disc passed through my hands, I began to feel more and more the strangeness of the moment. I knew Ellison had died here, after a short illness. I was later to learn that he had died in this very room, a few feet from where I was standing, in a special hospital bed brought in so that he could remain at home until the end. That event had occurred twelve years earlier, and for all its physical proximity, it still seemed a remote occurrence. Some of Ellison's most cherished possessions, artifacts which I also had my own fetishistic fascination, were passing through my fingers. It was an intimate experience. The writer was perhaps more fully "there" for me than he had ever been - and yet this moment was also about my direct participation in the dismantling of the physical evidence of his existence.

What I found that day was indeed tangible: a truly comprehensive collection of Western classical, jazz, blues, Cante Flamenco and many oddities-about 540 pieces in all. There were LPs, a smattering of $45 \mathrm{~s}$, and a fair crop of 78s, in both the ten-inch and twelve-inch varieties.

Of the ten-inch 78s, about thirty of the total group of 115 were Duke Ellington records, and the vast majority of discs in that overall group were jazz, blues, gospel, rhythm and blues or dance music of some sort, as in: Xavier Cugat, Fred Waring, Les Brown or Georgia Gibbs. The remaining ten-inch 78s were classical records, spoken word, or popular music. Included among the Ellington 78s were many recordings by the famous "Blanton-Webster" band of the early 1940s, including such tunes as: "I Let A Song Go Out of My Heart," "Cottontail," "Flamingo," "Main Stem," "Five O'clock Drag," "I'm Beginning to See the Light," "Jack the Bear," and "Don't Get Around Much Anymore."

Other jazz items include several Louis Armstrong 78s. Sadly, though, there was no Ellisonian Rosetta Stone: an early, preciously guarded copy of Armstrong's 1929 recording of "(What Did I Do to Be So) Black and Blue" was conspicuously absent.

If the records themselves are to function as signposts in their own right - they are now housed at the National Jazz Museum in Harlem - it may be instructive to focus on the Ellington Orchestra for a moment: Ellison had a long and well documented dedication to Edward Kennedy "Duke" Ellington and his music, and 
held up Ellington and his musicians as the most creative, enigmatic and nuanced figures in all of jazz. He lauded Ellington's compositions as achievements of the highest order. In a posthumously published letter to his colleague and confidant Albert Murray, he recounted a moment when one of his students insisted on playing a "pile" of Charlie Parker records on the Ellisons' home stereo. The writer was no lover of modern jazz, which he found gratuitous and empty: "I thought I'd die before he finished playing that pitiful blat of misplaced ambition and ego," he wrote to his friend, referring to Parker. "I spent the rest of the evening playing Duke to cleanse the atmosphere."

In his "Homage to Duke Ellington on His Birthday," Ellison asked the question: "How many generations of Americans, white and black, wooed their wives and had the ceremonial moments of their high school and college days memorialized by Ellington's tunes?"3

We can only speculate, but among the most heavily played of the Ellison 78 s is the 1938 perennial "I Let a Song Go Out of My Heart." The tune was first recorded in March of that year and released as disc number 8108 on Brunswick's black and silver label. Ellison met his first wife, Rose Poindexter, that spring. ${ }^{4}$

Of the entire body of 78s, among the non-Ellington grouping are some fine recordings, mostly by black artists: e.g., Teddy Wilson with Billie Holiday doing their 1938 rendition of Shay, Fisher and Goodwin's "When You're Smiling," with its dynamic Lester Young tenor solo; a 1939 Benny Carter Orchestra record; a King Pleasure record; Sarah Vaughan's recording of "I Feel So Smoochie" to name a few. There were also some requisite items from the post war era (and many popular recordings from the 1950s) including records by the Ink Spots, the Mills Brothers, Louis Jordan, Wynonie Harris, Dusty Fletcher, Benny Goodman, and the Woody Herman Orchestra. Danceable stuff. In those days everybody danced, and most people danced reasonably well. If one didn't venture out to a nightclub, most likely one would have invited people over to the house or apartment to eat and drink and to listen to records - to dance in the living room, and literally "cut the rug."

Of the longer playing, twelve-inch 78 s there were a few pop items, but as the twelve-inch 78 was designed to accommodate more music than the ten-inch version, with its three-minute limit, it was perfect for the classical collector. Among those older classical discs in the Ellisons' house were works by Ludwig van Beethoven, Giuseppe Verdi, Sergei Prokofiev, Ernest Bloch, Modest Mussorgsky, Anton Webern and Camille Saint Saens. There was Vladimir Horowitz playing Sergei Rachmaninoff, a three-disc album of Igor Stravinsky's Firebird Suite, music by Hector Berlioz - and Bachiana No 5, by Heitor Villa Lobos, which would seem to presage Ellison's fascination with Latin-derived music, and particularly his later interest in Flamenco.

The LPs, however, make up the main body of the collection. Of the 360-odd LPs, sixty of them are by Duke Ellington or are Duke Ellington-related records. So if one wants to go by the LPs (especially as one enters the LP era, which is roughly post 1948) Ellison was spending almost twenty percent of his listening 
time with Duke, or "the Master," as he called him. About 150 of the LPs are Western classical. I am no authority on this genre, but I would characterize this grouping as a "thinking man's classical collection." There are the requisite works by J.S. Bach, Johannes Brahms, Beethoven, Franz Schubert, Stravinsky and Gustav Mahler. But there are also more modernist works by Benjamin Britten, Paul Hindemith, Aram Khachaturian, Alban Berg, and Michael Tippet.

Ellison dug the popular Russian virtuosi of the day, especially Mstislav Rostropovich and Sviatoslav Richter. We know he liked singers. I found records featuring the divas Bidu Sayo, Joan Sutherland, Leontyne Price, Kathleen Ferrier, and Jennie Tourel.

He also seems to have had a penchant for oboe, as there were more than a few oboe records in the house. The voice of the oboe in Western classical music and in film scoring is often used to denote melancholy, grief or tragedy.

With a nod to potential musical inspirations for his ex jazz musician turned preacher, Alonzo Z. Hickman, one of the central characters of Ellison's nevercompleted second novel, (now known as Three Days Before the Shooting...), I would refer listeners to the entire Ellington trombone section of the 1930s and early 1940s, including Juan Tizol and Lawrence Brown, but particularly to the "talking" style of the great Joe "Tricky Sam" Nanton, who is most likely the model for Hickman as musician. Talking or "preaching" on a trumpet or trombone, an idiosyncratic technique and the special province of African American players of the first half of the $20^{\text {th }}$ century, represented for Ellison an undeniable example of black musical genius, and the triumph of the vernacular over the constraints of form and the stuffiness of the Western classical approach to brass instrumental technique. As embraced by Nanton, it became more than simply a high form of folk art, but rather a deeply articulate expression of emotive expansiveness and beauty.

In the end, of course, this is a subjective process. We all have objects in our homes that may have arrived there arbitrarily. Some were likely gifts. Some brought there by Fanny or other family members. The fact that Ellison owned a record does not necessarily signify that he played it. But these artifacts are interesting clues to Ellison's aesthetic and to stylistic models that he may have referenced.

Alban Berg's modernistic opera, Wozzeck, a recorded copy of which Ellison owned, is about a soldier who is psychologically cut off from society, not because of his race or class, but because he has fathered a child out of wedlock. Wozzeck sees visions of fire and death and experiences a surrealistic distancing not unlike that experienced by the main character in Invisible Man, and by the Bliss/Sunraider character in Three Days Before the Shooting.... This libretto may have served as source material for the dreams and surrealistic visions in Ellison's fiction, especially in his second book. Opera, of course, has its broader appeal. Ellison was nothing if not conscious of the art of stagecraft.

Today, almost a decade later, when I think back on my brief encounter in the Ellison home, I am reminded of another experience I had more recently. 
In the spring of 2014, I was invited to speak at the Ralph Ellison Centennial Symposium, which was the centerpiece of the annual Multi Ethnic Literature of the United States conference, held in downtown Oklahoma City at the Skirvin Hotel, where Ellison had reputedly worked as a teenager. The day after the conference, I signed up for a Sunday morning walking tour of "Deep Second" or "Deep Deuce," the East $2^{\text {nd }}$ Street neighborhood where Ellison grew up. I didn't know what to expect, but I was excited by the prospect of finally being "on site" in what I still consider to be one of the most important locales in the country. Nursing a cold, and a mild hangover on top of it, I gathered with other faithful Ellisonians in the hotel's lobby, and we listened as a guide explained that Deep Deuce was just a few blocks away. She showed us aerial photographs on her IPad, and explained that much had changed since Ellison's time. I listened with half an ear as I sipped my coffee, my head pounding.

We hit the street, walking past a wall filled with murals that depicted an historical timeline of Oklahoma City. White faces, mostly. We crossed under a train trestle. Our guide slowed her pace and then stopped.

"You're in the heart of it," she said, gesturing to a cluster of brick buildings behind her. "This is Ellison's home turf."

I looked around, confused. Apart from an old church which had been converted into a law firm and a handful of two story brick buildings, spaced blocks apart, we were looking mostly at contemporary institutional style cinderblock structures, with balconies and built in air conditioning units hanging off their facades. There were no frame houses, no Slaughter Building, no barbershops, no grocery stores. And certainly no people. In fact, there was nobody around. Not a soul. I felt a sharp tinge of sadness.

"Who lives here?" I asked.

"Mostly students; there's some subsidized housing, some new construction. But this neighborhood was pretty much razed in the 1960s. At that time, I think there were about ten or twelve buildings left. Now there are only a few from the old days. As you can see, there's a lot of open space."

Open space. The opposite of what I had seen in my mind's eye. I had expected, if not a bustling black downtown circa 1930, that at the very least there would be some people here, some semblance of life. But there were no storefronts, no businesses. It had all been wiped off the map.

There was a place for breakfast, and it turned out that there were two or three structures to take in. The Aldridge Theater, where the seminal Southwestern swing band the Blue Devils had once performed in the pit for Cecil B. DeMille's 1925 film production of The Ten Commandments, was still there. ${ }^{5}$ There was a brick house around the corner, said to be not unlike the one that Ralph Ellison had lived in as a boy. The author's personal narrative, his connection to the community, was strong enough in and of itself that it held our attention, even though there was almost no set, or stage, on which to place it. The most compelling aspect of the place was its virtual quality, its non-presence. 
What I encountered in apartment $8 \mathrm{D}$ has stayed with me over the years. As I left that day, never to return to a place where Ellison had lived and died, I felt the full blast of the New York City summer once again. And it occurred to me that the experience was significant not so much for any revelations I may have had about the author but more for a re-organization of my own thinking about music, and a re-contextualization of my youthful idealization of Ellison.

The records, of course, were never meant to be anything other than what they were: a private collection, a representation of one man's particular set of tastes and developing sensibilities. That they belonged to the writer Ralph Ellison, of course, makes them a strong reflection of his overall aesthetic, and, again, part of the building blocks of that aesthetic as he grew to become a major artist. As I discovered later, he was not the flawless being that I had made him out to be: multiple passages in Three Days Before the Shooting..., published posthumously, expose the older Ellison as remarkably self-conscious and often unfocused-as a writer struggling with his material.

And yet, in that second book that was never to be, there is some exemplary writing about music and the art of performance that suggests a deep understanding of not only the hypocrisy inherent in American society; the psychology, style and temperament of a jazz musician; but also of the hidden, unspoken relationships between people that are too often obscured by barriers of race and class. One passage addresses this as an aspect of the interiority of the jazzman turned preacher, Alonzo Z. Hickman:

Because of his love for his art, his delight in performing, and the satisfaction which sprung from his ability to release the hidden pleasures of the dance, he had clung to jazz as to his innermost sense of his identity. Thus more often than not he had given his employers his best out of a recognition that one part of his dual role went with the other, and that no matter how deeply their artistic roles were examined, and regardless of their color or their backgrounds, all entertainers-including opera singers and virtuoso violinists, were just that-entertainers. Like them he was an artist who served the whims of the anonymous public. But beyond that there remained those mysterious aspects of what one did through one's art which could not be reduced to terms of money, social status or color. And somewhere in that mystery he had found the saving grace of his art. ${ }^{6}$

Ellison understood music and musicians better than most. He also understood relationships between people, places and things and articulated them in a way that allowed for his readers to inhabit his vistas and his characters, to leave the trappings and parameters of their own lives, and to connect with the multidimensionality of the American black experience. For me, the simple task of ensuring that Ralph Ellison's records ended up in the archives of the National Jazz Museum in Harlem, where scholars of later generations will undoubtedly seek them out, converting signification into meaning - this act brought me a bit closer to a special understanding of what made the man tick. But more important, it afforded me a personal view of Ellison the person, the man in $8 \mathrm{D}$ - who despite 
his best efforts to achieve a further guarantee of immortality—struggled to live up to his own self-expectations, to continually abide in the spirit and power of his own vision, and who, in the end, was a citizen of the world, one who liked to sing, play, dance, drink, and marvel at the great variety and virtuosity of life, underscored by a soundtrack to dream on.

\section{Notes}

1. A representative sample of Ellison's Duke Ellington ten-inch (standard size) 78s: Solitude/ Delta Serenade, January 10, 1934; There's a Lull in My Life/It's Swell of You, April 9, 1937; I Let a Song Go Out of My Heart/The Gal from Joe's, Feb/March 1938; The Sergeant Was Shy/Serenade to Sweden, June/August 1939; Morning Glory/Jack the Bear, March 6, 1940; Cotton Tail/Don't Get Around Much Anymore, May 4, 1940; Flaming Sword/Warm Valley, October 17, 1940; Flamingo/The Girl in my Dreams Tries to Look Like You; December 28, 1940; Rock's in My Bed/Bli Blip, September 26, 1941; Five O'Clock Drag/Clementine, September 26, 1941; Perdido/Raincheck, December 1941/January 1942; Moon Mist/C-Jam Blues, January 1942; I Don't Mind/What Am I Here For?, February 26, 1942; Main Stem/Johnny Come Lately, June 26, 1942; Don't You Know I Carel I'm Beginning To See The Light, December 1, 1944; I Didn't Know About You/ I Ain't Got Nothin'But The Blues, December, 1944; Time's a Wastin'/ Every Hour on the Hour, May 16, 1945; Jam-a-ditty/ Diminuendo in Blue, fall/winter, 1946; There's a Lull in my Life/ It's Swell of You, spring, 1947; It's Monday Every Day/ Air Conditioned Jungle, fall, 1947; On the Sunny Side of the Street/ Good Woman Blues, December 22, 1949; Ultra Deluxe/ Blue Moon, December, 1953. Ellison most likely bought many of these records as they were released, but being a collector, he may also have sought them out years after their initial release date, and thus we cannot say exactly during which period he first encountered them or exactly when (or how often) he listened to them. 78 records generally were available in stores within three weeks to a month after being recorded.

2. Ralph Ellison and Albert Murray, Trading Twelves (New York: Vintage Books), 205-206.

3. Ralph Ellison, "Homage to Duke Ellington on His Birthday," from Going to the Territory (New York: Random House, 1986) as reprinted in The Collected Essays of Ralph Ellison (New York: Random House, 1995), 677.

4. Rampersad, Arnold, Ralph Ellison: A Biography (New York: Alfred A. Knopf), 109-110.

5. Todd Bryant Weeks, Luck's in My Corner: the Life and Music of Hot Lips Page (New York: Routledge Press), 54.

6. Ralph Ellison, Three Days Before the Shooting... (New York: Random House), 590. 